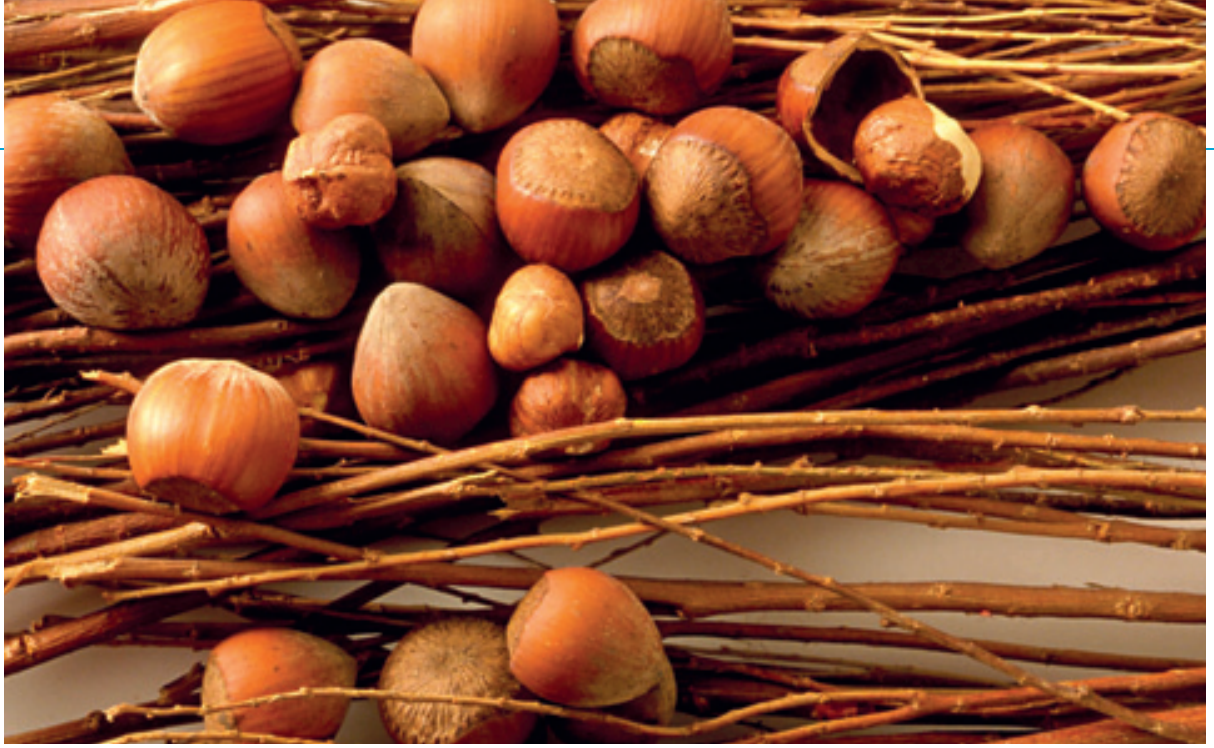

Illustrasjonsfoto Colourbox

\title{
Nøtter gir gunstigere lipidprofil
}

\section{Daglig inntak av nøtter påvirker lipid- profilen i gunstig retning og effekten er doseavhengig.}

Flere tidligere studier har vist at et regelmessig inntak av nøtter kan ha effekter på lipidprofilen, men resultatene har ikke vært entydige. I en metaanalyse ble individuelle primærdata fra 25 tidligere studier i sju land med til sammen 583 deltakere analysert (1).

Resultatene viste at med et gjennomsnittlig daglig inntak på $67 \mathrm{~g}$ nøtter kan man estimere et gjennomsnittlig fall i totalkolesterolnivå på $0,28 \mathrm{mmol} / \mathrm{l}$, et fall i LDL-nivå på $0,26 \mathrm{mmol} / \mathrm{l}$, samt også signifikant reduksjon av LDL/HDL-ratioen. Triglyseridnivået ble signifikant redusert hos dem som hadde et høyt utgangsnivå, men ikke for dem med lavere utgangsnivå. Effektene var doseavhengige, og ulike typer nøtter hadde lik effekt på lipidprofilen. Personer med lav kroppsmasseindeks, høyt utgangs- nivå av LDL og et vestlig kosthold hadde best effekt av nøttespisingen.

- Folk flest tenker på nøtter som svært energirike matvarer som bør være en begrenset del av kostholdet. Nøtter inneholder imidlertid gunstige fettsyrer, plantesteroler og andre stoffer som er forbundet med redusert risiko for hjerte- og karsykdom. Nøtter bør spises ristet eller rå uten salt - krydder kan tilsettes. Ved fedmebehandling har nøtter en plass $i$ et middelhavskosthold, men mengden må begrenses, sier overlege Serena Tonstad ved Oslo universitetssykehus.

\section{Are Brean}

are.brean@legeforeningen.no

Tidsskriftet

\section{Litteratur}

1. Sabaté J, Oda K, Ros E. Nut consumption and blood lipid levels: a pooled analysis of 25 intervention trials. Arch Intern Med 2010; 170: 821 - 7 .

\section{Koffein ved claudicatio intermittens?}

Det er få muligheter for medisinsk behandling av claudicatio intermittens. Nå har danske forskere vist at koffein kan være gunstig (Br J Surg 2010; 97: 1503-10).

Den randomiserte studien omfattet 88 ambulante pasienter med claudicatio intermittens. De skulle være koffeinabstinente 48 timer før undersøkelsen og fikk deretter koffein oralt $(6 \mathrm{mg} / \mathrm{kg}$ ) eller placebo. Undersøkelsen foregikk 75 minutter etter.

Koffein økte den smertefrie gangdistansen fra 80 meter til 90 meter, og den maksimale gangdistanse ble økt fra 220 meter i placebogruppen til 320 meter i koffeingruppen. Også muskelstyrken og utholdenheten økte signifikant.

At ca. fem kopper kaffe eller ti kopper te kan forbedre gangdistansen er et originalt funn, men må etterprøves i flere studier, sier professor Torben V. Schroeder, Karkirurgisk Klinik, Rigshospitalet til Ugeskrift for Læger.

\section{Tai chi lindrer ved fibromyalgi}

Tai chi kan være en anvendelig behandling til pasienter med fibromyalgi. Dette viser en enkeltblindet, randomisert studie. Forskerne sammenliknet klassisk Yang-tai chi med en kontrollintervensjon bestående av velværeundervisning og strekkøvelser. $\emptyset$ velsene foregikk to ganger en time om uken i 12 uker for 66 deltakere ( $N$ Engl J Med 2010; 363: 743-54).

I tai chi-gruppen var det klinisk betydningsfulle forbedringer vurdert ved Fibromyalgia Impact Questionnaire (FIQ) og ved vurdering av livskvalitet. Det var også en gunstig virkning ved flere andre subjektive og objektive tester. Forbedringer ble bibeholdt etter 24 uker, og det var ingen bivirkninger.

\section{Lavkarbo eller fettfattig?}

\section{Både karbohydratfattig kost og fett- fattig kost, kombinert med generelle livsstilsråd, gir stabilt vekttap etter to år. Karbohydratfattig kost gir størst økning i HDL-kolesterolnivå.}

Studier om diettbehandling mot overvekt har vist varierende resultater innen ett år og omfatter ofte ikke råd om fysisk aktivitet og andre livsstilsendringer.

I en amerikansk studie ble 307 overvektige voksne personer uten hyperkolesterolemi og type 2-diabetes randomisert til å følge et kostopplegg med lavt karbohydratinnhold eller lavt fettinnhold (1). Gjennomsnittlig kroppsmasseindeks var 36,1. Alle deltakerne fikk råd og veiledning om økt fysisk aktivitet og andre livsstilsendringer. Etter ett år var gjennomsnittlig vekttap rundt $11 \%$ og etter to år rundt $7 \% \mathrm{i}$ begge gruppene. Gruppen som spiste karbohydratfattig mat hadde størst økning i HDL-kolesterolnivå. Endringer $\mathrm{i}$ andre metabolske forhold var lik $i$ begge gruppene.

- Denne studien viser at intensiv livsstilsintervensjon i form av gruppebasert atferdsterapi kan gi god og varig vektreduksjon, sier senterleder Jøran Hjelmesæth ved Senter for sykelig overvekt i Helse Sør-Øst ved Sykehuset i Vestfold. Den bekrefter også at samlet redusert kaloriinntak er viktigere enn valget mellom karbohydratfattig og fettfattig kost. Forskjellen i bedring av HDL-kolesterolnivå mellom gruppene var imidlertid liten, og personer med fedmerelaterte følgesykdommer var ikke tatt med. Den kliniske relevansen av dette funnet er dermed usikker, påpeker han.

- Opplegget i studien er svært ressurskrevende med tett og regelmessig oppfølging. Det store frafallet tyder på at spesifikke dietter, spesielt karbohydratfattig diett, kan være vanskelig å følge over tid, sier Hjelmesæth.

\section{Petter Gjersvik}

petjense@online.no

Tidsskriftet

\section{Litteratur}

1. Foster GD, Wyatt HR, Hill JO. Weight and metabo lic outcomes after 2 years on a low-carbohydrate versus low-fat diet. A randomized trial. Ann Intern Med 2010; 153; 147-57. 